\title{
PENGARUH PERBEDAAN TIPE KEPRIBADIAN TERHADAP SIKAP BELAJAR MATEMATIKA SISWA SMA ISLAM AL-AZHAR 5 CIREBON
}

\author{
Widodo Winarso
}

\begin{abstract}
Abstrak
Kepribadian merupakan sifat hakiki individu yang tercermin pada sikap peserta didik. Keunikan tersebut tergantung pada tipe kepribadian yang dimiliki.Tipe kepribadian tersebut mempengaruhi sikap dalam menyesuaikan diri dan bersosialisasi dengan lingkungan, termasuk dalam proses pembelajaran. Sikap belajar adalah kecenderungan perilaku saat mempelajari yang bersifat akademik dan merupakan salah satu faktor yang mempengaruhi hasil belajar. Sikap terkadang didasari oleh emosi dan dorongan dari dalam diri, dengan dorongan yang baik maka akan menghasikan sikap belajar yang baik pula dan begitu pula sebaliknya. Penelitian ini bertujuan untuk mengetahui perbedaan sikap belajar matematika siswa berdasarkan tipe kepribadian di SMA Islam Al-Azhar 5 Cirebon. Pendekatan yang digunakan dalam penelitian yakni kuantitatif dengan metode deskriptif. Populasi dalam penelitian ini adalah siswa SMA Islam AlAzhar 5 Cirebon, sedangkan sampelnya adalah siswa kelas $X$ berjumlah 98 orang. Teknik sampling yang digunakan dalam penelitian ini adalah probability sampling dengan menggunakan simple random sampling. Berdasarkan hasil analisis yang telah dilakukan bahwa tidak terdapat perbedaan sikap belajar matematika berdasarkan tipe kepribadian yang signifikan, hal ini dapat dilihat dari $F_{\text {hitung }}$ hasil uji one way anova yang dilakukan lebih kecil dari $F_{\text {tabel }}$ yaitu 0.616 dimana $F_{\text {tabel }}$ nya adalah 2,7 maka $H_{0}$ diterima artinya tidak terdapat perbedaan yang signifikan antarasikap belajar berdasarkan tipe kepribadian siswa.
\end{abstract}

Kata Kunci. tipe kepribadian dan sikap belajar Matematika 
Widodo Winarso

\section{Pendahuluan}

Pendidikan adalah proses pengubahan sikap dan tata laku seseorang/kelompok orang dalam usaha mendewasakan manusia melalui upaya pengajaran dan latihan agar dapat memajukan kesempurnaan hidup yaitu hidup dan menghidupkan anak yang selaras dengan alam dan masyarakatnya. Pendidikan sebagai sebuah sistem terdiri dari sejumlah komponen. Interaksi antar komponen berperan dalam menentukan berhasil atau tidaknya tujuan pendidikan.

Pendidik dan peserta didik merupakan salah satu dari komponen pendidikan tersebut. Seperti yang kita ketahui bahwa setiap peserta didik mempunyai kepribadian yang berbeda dan unik. Sunaryo dalam Septiarini (2011 : 1) menyatakan bahwa setiap individu adalah unik, artinya bahwa manusia yang satu berbeda dengan manusia yang lain dan tidak ada manusia yang sama persis dimuka bumi ini walaupun dilahirkan kembar.

Sebagai pendidik yang baik, guru diharuskan untuk memahami kepribadian peserta didiknya agar proses pendidikan bisa berlangsung dengan baik, sehingga bisa mendapatkan hasil yang maksimal dalam pembelajaran. Kepribadian adalah ciri atau karakteristik atau gaya atau sifat khas dari diri seseorang yang bersumber dari bentukan-bentukan yang diterima dari lingkungan, misalnya, keluarga pada masa kecil, dan juga bawaan seseorang sejak lahir (Sjarkawi, 2006 : 11).

Kepribadian merupakan sifat hakiki individu yang tercermin pada sikap dan perbuatannya yang unik, yang membedakan dirinya dengan yang lain. Keunikan tersebut tergantung pada tipe kepribadian.

Tipe kepribadian diperkenalkan pertama kali oleh Hippocrates (460370 SM) yang kemudian disempurnakan oleh Galenus, yang membaginya menjadi empat tipe berdasakan jenis cairan yang paling berpengaruh pada tubuh manusia yaitu chole, sanguis, flegma dan melanchole (Fauzi, 1997 : 124). Tipe kepribadian tersebut dikembangkan lagi oleh Littauer dalam bukunya yang berjudul Personality Plus. 
Pengaruh Perbedaan Tipe Kepribadian Terhadap Sikap Belajar Matematika Siswa SMA Islam Al-Azhar 5 Cirebon

Littauer (1996 : 22-27) mengungkapkan bahwa terdapat 4 tipe kepribadian yang dimiliki oleh manusia, tipe kepribadian tersebut adalah tipe kepribadian koleris kuat, kepribadian sanguinis yang popular, kepribadian melankolis yang sempurna dan kepribadian phlegmatis damai. Dia menjelaskan bahwa orang dengan tipe kepribadian sanguinis populer sangat suka dengan pujian dan pusat perhatian. Hampir sama dengan sanguinis, orang tipe koleris memiliki ambisi untuk menjadi lebih dominan di antara orang-orang lain di sekitarnya. Orang dengan tipe kepribadian koleris memiliki kemauan keras dalam mencapai sesuatu dan orang dengan tipe melankolis terkenal karena perfeksionisnya, mereka terobsesi dengan hasil yang sempurna dan tidak mengecewakan mereka.

Keempat tipe kepribadian tersebut mempengaruhi sikap dan perilaku seseorang dalam menyesuaikan diri dan bersosialisasi dengan lingkungan disekitarnya, termasuk dalam proses pembelajaran. Pada proses pembelajaran, siswa dinilai mulai dari sikap hingga hasil belajarnya. Tipe kepribadian ini jugalah yang menunjukan keunikan sikap seseorang terhadap suatu objek.

Sikap adalah suatu kecenderungan seseorang dalam menilai dan bereaksi terhadap suatu objek yang diikuti dengan perasaan positif atau negatif, dimana perasaan positif adalah perasaan yang bisa menerima objek tersebut dan perasaan negatif ini adalah perasaan yang menolak objek tersebut. Sikap belajar adalah kecenderungan tindakan siswa terhadap suatu pelajaran yang terwujud dalam bentuk perasaan senang atau tidak senang, setuju atau tidak setuju, suka atau tidak suka terhadap pelajaran yang dipelajari (Djaali, 2008 : 116).

Matematika merupakan salah satu komponen dari serangkaian mata pelajaran yang mempunyai peranan penting dalam pendidikan, yang dapat mendukung perkembangan ilmu pengetahuan dan teknologi. Tidak mengherankan jika pelajaran matematika dalam pelaksanaan pendidikan diberikan kepada semua jenjang pendidikan, mulai dari sekolah dasar hingga perguruan tinggi. 
Namun pada kenyataannya, matematika merupakan pelajaran yang kurang disukai bahkan dibenci oleh sebagian siswa dikarenakan sifatnya yang abstrak. Hampir semua siswa mempunyai sikap belajar yang negatif terhadap matematika. Di lapangan, sebagian siswa biasa mengatakan"saya senang belajar matematika, gurunya ramah, dan penjelasannya mudah dimengerti”. Namun kebanyakan dari mereka sering mengatakan "saya tidak senang belajar matematika, susah mempelajarinya, dan banyak rumusrumus yang perlu dihafal". Hal ini mencerminkan sikap siswa terhadap pelajaran matematika, baik berupa sikap positif maupun sikap negatif.

Matematika sebagai salah satu pelajaran yang dipersepsikan masyarakat sebagai salah satu pelajaran yang dianggap sulit dan hanya sebagian orang yang dianggap mempunyai tingkat kecerdasan tertentu yang mampu menguasai dan mendapat hasil yang bagus dalam proses pembelajarannya membuat orang yang mampu menguasai pelajaran ini mempunyai keistimewaan tersendiri dan dianggap hebat sehingga mendapat pujian, penghargaan dan jadi pusat perhatian dari orang-orang.

Berdasarkan konsep diatas, dapat dimaknai bahwa pertama orang sanguinis suka dengan pujian dan menjadi pusat perhatian, persepsi di atas menjadi salah satu motivasi mereka dalam belajar matematika sehingga sikap mereka dalam belajar mereka akan mengarah pada sikap yang positif. Kedua orang dengan tipe kepribadian koleris memiliki ambisi untuk menjadi lebih dominan di antara orang-orang lain di sekitarnya dan memiliki kemauan keras dalam mencapai sesuatu. Inilah yang memotivasi orang koleris dalam belajar matematika. Ketiga orang dengan tipe kepribadian melankolis terkenal karena perfeksionisnya, mereka terobsesi dengan hasil yang sempurna dan tidak mengecewakan mereka. Inilah yang memotivasi mereka dalam melakukan suatu pekerjaan atau kegiataan termasuk dalam belajar matematika. Keempat orang tipe phlegmatis yang mempunyai sikap pemalu dan tidak suka menonjolkan diri, lebih memilih biasa saja dalam pembelajaran matematika sehingga mereka tidak perlu menjadi pusat perhatian orang-orang. 
Pengaruh Perbedaan Tipe Kepribadian Terhadap Sikap Belajar Matematika Siswa SMA Islam Al-Azhar 5 Cirebon

Berdasarkan studi pendahuluan yang dilakukan penulis di SMA Islam Al-Azhar 5 Cirebon melalui wawancara dengan ibu Mega Fitriyanti, S.Pd selaku guru mata pelajaran matematika kelas $X$ dan XI pada tanggal 6 Maret 2014 pkl. 10.30 WIB, sekolah memiliki program pengembangan kepribadian bagi siswa-siswanya terutama dalam bidang keagamaan. Program ini diberikan kepada anak didik melalui kegiatan wajib keagamaan seperti sholat dhuha dan sholat dzhuhur di sekolah. Sedangkan untuk siswi yang berhalangan untuk melaksanakan kewajiban ini maka diganti dengan kegiatan keputriaan yang diisi oleh guru sebagai narasumber yang dilaksanakan pada waktu dzuhur.

Sekolah meyakini dengan pembekalan agama yang baik maka kepribadian anak didik pun akan baik. Hal ini dilihat dengan tingkat disiplin yang baik dan sikap belajar yang aktif, baik pada saat pembelajaran matematika maupun pembelajaran lainnya, disini kita tidak akan menjumpai siswanya yang membolos di kantin pada saat pembelajaran berlangsung, selain itu jika ada guru yang telat masuk kelas atau berhalangan hadir maka siswanya sendiri yang akan inisiatif untuk memanggil atau menanyakan kepada guru piket adakah tugas untuk mereka.

Berdasarkan fenomena di atas, maka penulis merasa tertarik untuk mengkaji lebih dalam tentang Pengaruh Tipe Kepribadian Terhadap Sikap Belajar Siswa SMA Islam Al-Azhar 5 Cirebon.

\section{Metode Penelitian}

Penelitian ini dilaksanakan di SMA Islam Al-Azhar 5 Cirebon. Penelitian ini menggunakan pendekatan kuantitatif, karena penelitian ini sifatnya akan mengukur ada tidaknya dan perbedaan sikap belajar matematika siswa SMA Islam Al-Azhaar 5 Cirebon berdasarkan tipe kepribadian yang dimiliki. Metode yang digunakan dalam penelitian ini adalah metode deskriptif. 
Dalam penelitian ini, yang menjadi populasi adalah siswa SMA Islam Al-Azhar 5 Cirebon. Namun, yang menjadi populasi target adalah siswa kelas X SMA Islam Al-Azhar 5 yang berjumlah 130 siswa. Teknik sampling yang digunakan dalam penelitian ini adalah probability sampling yaitu menggunakan simple random sampling. Dengan responden dalam penelitian ini berjumlah 98 orang responden.

Teknik pengumpulan data yang digunakan dalam penelitian ini adalah penyebaran kuesioner (angket). Alat ukur tipe kepribadian ini merupakan tes profil kepribadian dari Littauer (1996) yang terdiri dari 40 item pernyataan. Sedangkan penilaian untuk alat ukur sikap belajar matematika menggunakan skala likert dengan alternatif jawaban yaitu Sangat Setuju (SS), Setuju (S), Kurang Setuju (KS) danTidak Setuju (TS)

Teknik pengumpulan data dan pengolahan data dalam penelitian ini yakni melakukan prosedur mulai dari klasifikasi data, tabulasi data, pengolahan data dengan menggunakan perhitungan prosentase dari jumlah siswa yang memilih baik tipe kepribadian. Selanjtnya sebelum malakukan penelitian. instrument penelitian melalui tahap uji coba. Tahap uji coba terdiri dari uji validitas dan uji reabilitas.

Teknik analisis data dalam penelitian ini melalui tahap uji normalitas dengan menggunakan uji Kolmogorov-Smirnov. Uji homogenitas dengan mengunakan uji Homogeneity Of Variance Test. Selajutanya melakukan uji Hipotesis dengan mengunakan uji analisis uji $\mathrm{F}$ atau ANOVA (Analysis of Variance).

\section{Hasil dan Pembahasan}

1. Hasil Kecenderungan Tipe Kepribadian Siswa SMA Islam Al-Azhar 5 Cirebon

Untuk mengetahui kecenderungan tipe kepribadian apa saja yang dimiliki oleh siswa kelas X SMA Islam Al-Azhar 5 Cirebon, penulis menggunakan tes kepribadian yang terdapat dalam buku Florence Littauer yang berjudul Personality Plus yang terdiri dari 40 nomor, 
Pengaruh Perbedaan Tipe Kepribadian Terhadap Sikap Belajar Matematika Siswa SMA Islam Al-Azhar 5 Cirebon

dimana ditiap nomor terdiri dari deret empat kata ke samping. Responden diminta untuk men-cheklist $(\checkmark)$ satu kata yang paling cocok dengan diri mereka.

Berdasarkan penelitian yang dilakukan oleh penulis di SMA Islam Al-Azhar 5 Cirebon, didapat data hasil tipe kepribadian siswa. Untuk mengetahui lebih jelas mengenai tipe kepribadian siswa disajikan pada tabel berikut ini :

Tabel 1

Rekapitulasi Data Hasil Penelitian untuk Tipe Kepribadian

\begin{tabular}{|c|l|c|c|}
\hline No & Tipe Kepribadian & Frekuensi & Prosentase \\
\hline 1 & Sanguinis & 42 & $42,86 \%$ \\
\hline 2 & Melankolis & 19 & $19,39 \%$ \\
\hline 3 & Koleris & 18 & $18,36 \%$ \\
\hline 4 & Phlegmatis & 19 & $19,39 \%$ \\
\hline \multicolumn{2}{|c|}{ Jumlah } & 98 & $100 \%$ \\
\hline
\end{tabular}

Berdasarkan tabel rekapitulasi data hasil penelitian tipe kepribadian siswa di atas, hasil penelitian menunjukan bahwa dari 98 orang responden, tipe kepribadian sanguinis merupakan tipe kepribadian dominan yang dimiliki oleh siswa SMA Islam Al-Azhar 5 Cirebon. Dimana terdapat 42 atau sekitar $42,86 \%$ responden dengan tipe kepribadian sanguinis, 19 atau sekitar 19,39\% responden dengan tipe kepribadian melankolis, 18 atau sekitar 18,36\% responden dengan tipe kepribadian koleris dan 19 atau sekitar 19,4\% responden dengan tipe kepribadian phlegmatis.

\section{Hasil Sikap Belajar Matematika Siswa SMA Islam Al-Azhar 5 Cirebon}

Untuk mengetahui sikap belajar matematika siswa kelas X SMA Islam Al-Azhar 5 Cirebon, penulis menggunakan angket skala likert (skala sikap) yang terdiri dari 24 item pernyataan dan 10 indikator yaitu kesediaan mengikuti pembelajaran, senang dalam mempelajari matematika, aktif menanggapi apa yang disampaikan pada saat pembelajaran matematika berlangsung, antusias dalam proses pembelajaran, kemampuan penyelesaian tugas, meyakini pentingnya 
mempelajari matematika, memiliki kebiasaan positif dalam belajar matematika, percaya akan kemampuan yang dimiliki, mempersiapkan hal yang diperlukan dalam pembelajaran matematika dan berusaha menyelesaikan tugas yang diberikan guru.

a. Kesediaan mengikuti pembelajaran matematika

Kesediaan mengikuti pembelajaran matematika terukur melalui; Pertama, kehadiran siswa di kelas pada saat pembelajaran matematika karena mereka tidak ingin ketinggalan materi, dengan rincian masing-masing tipe kepribadian. diperoleh hasil perhitungan prosentase sebesar $85,46 \%$ atau hampir seluruhnya siswa mengikuti pembelajaran matematika.

\section{Gambar 1}

Rincian Kehadiran Siswa Berdasarkan Tipe Kepribadian

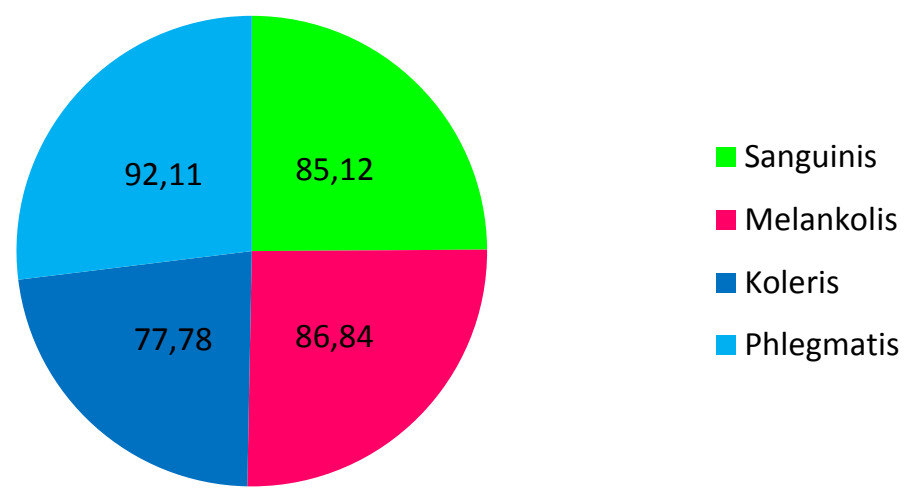

Kedua, konsentrasi siswa dalam mengikuti pembelajaran matematika. diperoleh bahwa $72,45 \%$ atau sebagian besar siswa suka mengantuk pada saat pembelajaran matematika karena guru matematika mereka lebih sering menggunakan metode ceramah dan kurang bervariasinya metode mengajar guru mereka dalam menerangkan pelajaran sehingga penjelesannya membesonkan 
Pengaruh Perbedaan Tipe Kepribadian Terhadap Sikap Belajar Matematika Siswa SMA Islam Al-Azhar 5 Cirebon

\section{Gambar 2}

Rincian Kosentrasi Siswa Berdasarkan Tipe Kepribadian

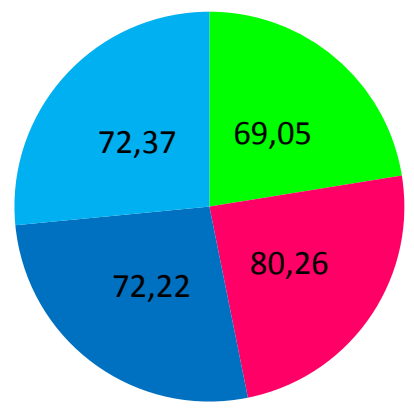

Sanguinis

- Melankolis

- Koleris

- Phlegmatis

b. Senang dalam mempelajari matematika

Senang dalam mempelajari matematika meliputi; Pertama, senang belajar matematika karena sifatnya abstrak. diperoleh $80,61 \%$ atau hampir seluruhnya siswa mempunyai ketertarikan dalam objek mental atau pikiran dilihat dari prosentase pernyataan siswa senang belajar matematika karena sifatnya abstrak yang berada pada kriteria sangat baik.

\section{Gambar 3}

Rincian Kesenangan Siswa Pada Sifat Abstrak Berdasarkan Tipe Kepribadian

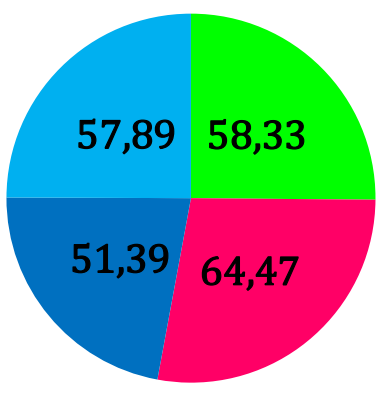

Sanguinis

Melankolis

- Koleris

Phlegmatis

Kedua, ketidaksukaan belajar matematika terhadap struktur matematika yang ketat. diperoleh bahwa $81,12 \%$ atau hampir seluruhnya siswa tidak suka belajar matematika karena tak ada sesuatu yang kreatif dalam matematika yang menumbuhkan minat dan ketertarikan mereka dan hanya bersifat mengingat rumus, dimana disetiap materi mereka akan selalu mendapatkan rumus yang mesti diingat agar bisa mengerjakan soal. 
Gambar 4

Rincian Ketidak Sukaan Terhadap Struktur Matematika Berdasarkan Tipe Kepribadian

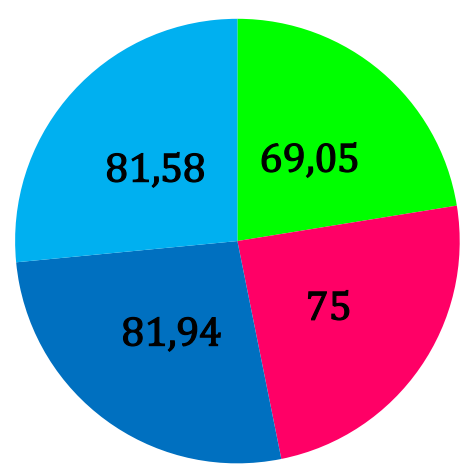

Sanguinis

Melankolis

Koleris

Phlegmatis

c. Aktif menanggapi apa yang disampaikan pada saat pembelajaran matematika berlangsung

Aktif menanggapi apa yang disampaikan pada saat pembelajaran matematika berlangsung meliputi; Pertama, kemampuan mengoreksi materi pembelajaran matematika. Diperoleh $70,92 \%$ atau sebagian besar siswa mengoreksi penjelasan guru matematika mereka jika memang terdapat kekeliruan dalam menjelaskan. Ini berarti mereka memperhatikan dan aktif menanggapi apa yang disampaikan oleh guru mereka.

\section{Gambar 5}

Rincian Kemampuan Mengoreksi Materi Pembelajaran Berdasarkan Tipe Kepribadian

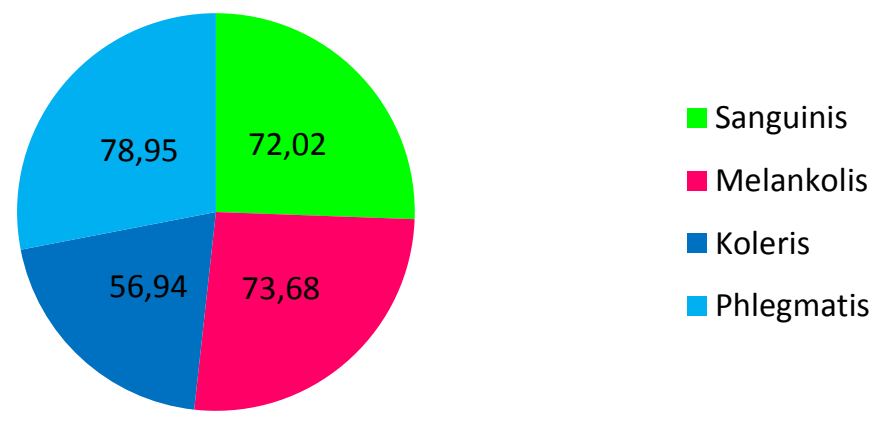

Kedua, kemampuan menjawab pertanyaan dari guru. diperoleh bahwa $75 \%$ atau sebagian besar siswa tidak akan mencoba menjawab pertanyaan dari guru mereka jika pertanyaan tersebut tidak ditujukan langsung kepada mereka. Mereka memilih diam jika 
Pengaruh Perbedaan Tipe Kepribadian Terhadap Sikap Belajar Matematika Siswa SMA Islam Al-Azhar 5 Cirebon

guru memberikan pertanyaan tanpa menyatakan pertanyaan tersebut ditujukan kepada salah seorang diantara mereka.

\section{Gambar 6}

Rincian kemampuan menjawab pertanyaan dari guru

Berdasarkan Tipe Kepribadian

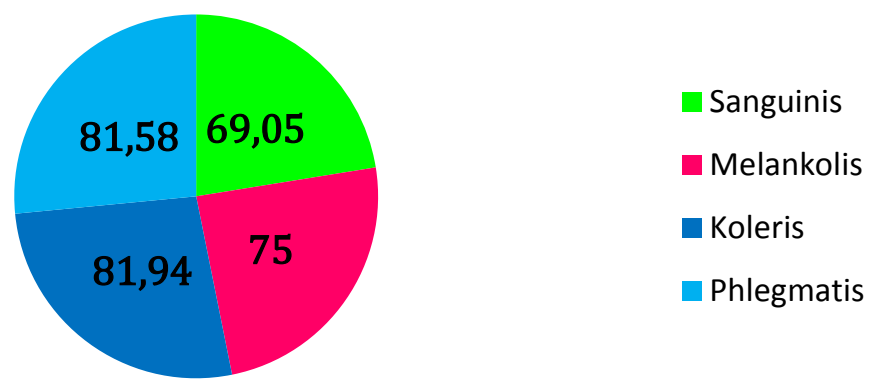

\section{d. Antusias dalam proses pembelajaran}

Antusiasme dalam proses pembelajaran meliputi; Pertama, sikap gugup dan senang terhadap matematika. Diperoleh $82,65 \%$ atau hampir seluruhnya siswa sangat setuju dengan pernyataan. Artinya ketegasan guru dalam mengajar membuat hampir seluruh siswa merasa gugup dan tidak senang dalam belajar matematika.

\section{Gambar 7}

Rincian Sikap Gugup dan Senang Berdasarkan Tipe Kepribadian

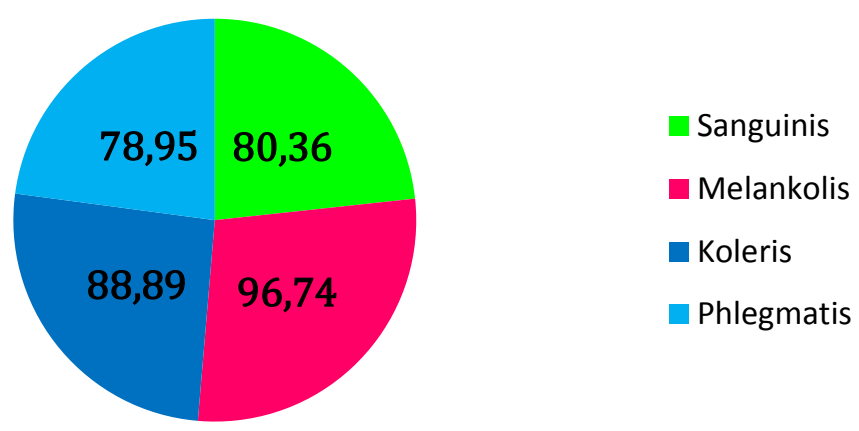

Kedua, kemampuan menangkap materi yang di ajarkan dalam pembelajaran matematika. Diperoleh bahwa $66,84 \%$ atau sebagian besar siswa setuju dengan pernyataan. Artinya sebagian besar siswa tidak akan bertanya kepada guru jika mereka tidak mengerti dengan apa yang dijelaskan oleh guru mereka. Hal ini bisa dikarenakan mereka malu untuk bertanya secara langsung kepada guru pada saat 
pembelajaran berlangsung, mereka memilih untuk bertanya kepada teman mereka yang lebih mengerti dari mereka.

\section{Gambar 8}

Rincian kemampuan menangkap materi pembelajaran

Berdasarkan Tipe Kepribadian

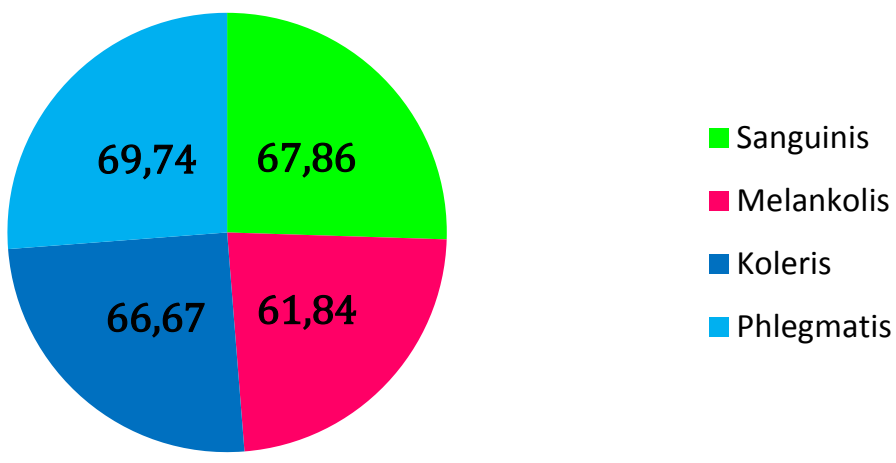

e. Kemampuan Penyelesaian Tugas Matematika

Kemampuan menyelesaikan tugas matematika meliputi; Pertama, mengerjakan tugas tepat waktu. Diperoleh $73,47 \%$ atau hampir seluruhnya siswa sangat setuju dengan pernyataan. Artinya para siswa mempunyai rasa tanggung jawab dalam mengerjakan tugas mereka karena mengerjakan tugas tepat waktu merupakan kewajiban bagi mereka.

\section{Gambar 9}

Rincian kemampuan mengerjakan tugas tepat waktu Berdasarkan Tipe Kepribadian

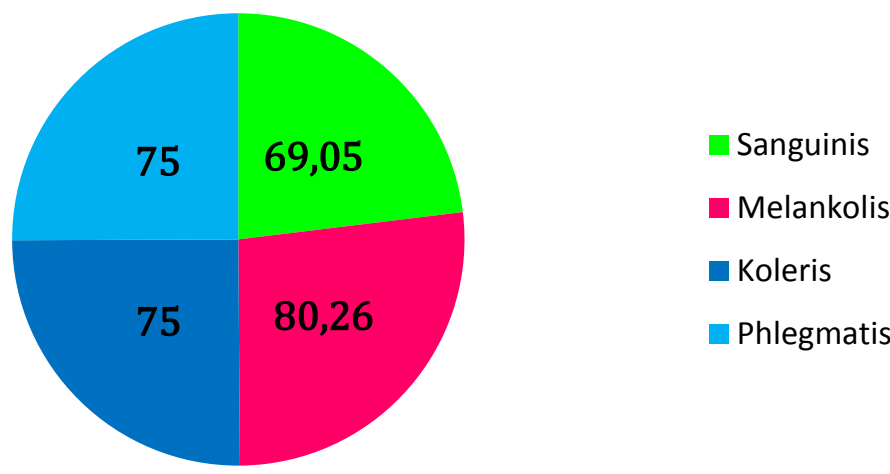


Pengaruh Perbedaan Tipe Kepribadian Terhadap Sikap Belajar Matematika Siswa SMA Islam Al-Azhar 5 Cirebon

Kedua, rasa putus asa dalam menerjakan tugas matematika, diperoleh bahwa $67,86 \%$ atau sebagian besar siswa setuju dengan pernyataan. Artinya sebagian besar siswa merasa putus asa jika tidak bisa menyelesaikan soal mereka. Para siswa lebih memilih tidak mencari tahu penyelesaian soal matematika dengan kemampuan mereka. Hal ini bisa disebabkan karena mereka tidak peduli jika mereka bisa menyelesaikan soal matematika.

\section{Gambar 10 \\ Rincian Rasa Putus Asa Dalam Mengerjakan Tugas Matematika \\ Berdasarkan Tipe Kepribadian}

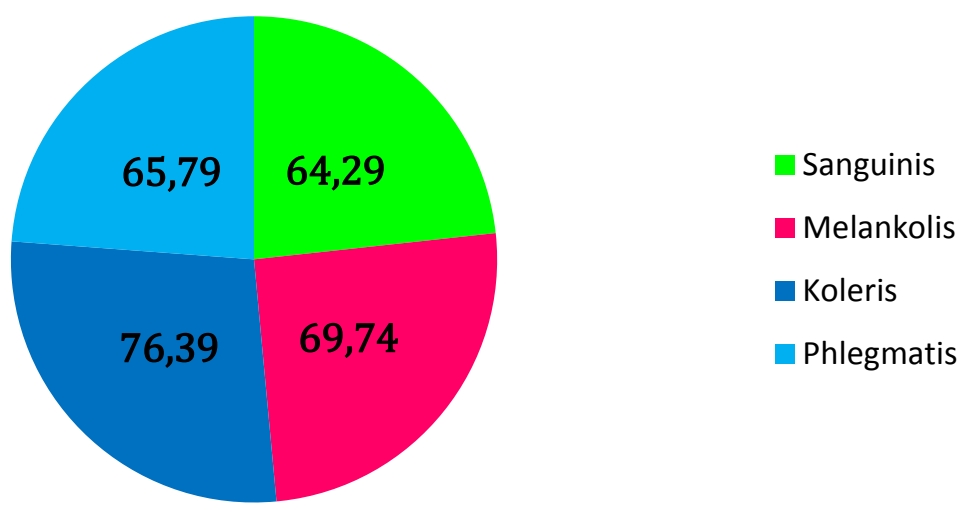

\section{f. Meyakini Pentingnya Mempelajari Matematika}

Meyakini pentingnya mempelajari matematika meliputi; Pertama, mengetahui manfaat matematika pada kehidupan sehari-hari. Diperoleh 66,58\% atau sebagian besar siswa setuju dengan pernyataan. Artinya para siswa pada dasarnya tahu kegunaan matematika dalam kehidupaan sehari-hari yaitu untuk menghitung, tapi mereka kurang menyukai pembelajaran matematika karena tidak ada sesuatu yang kreatif pada pelajaran matematika bagi mereka dan hanya bersifat mengingat rumus. 


\section{Gambar 11}

Rincian Mengetahui Manfaat Matematika Pada Kehidupan Sehari-Hari Berdasarkan Tipe Kepribadian

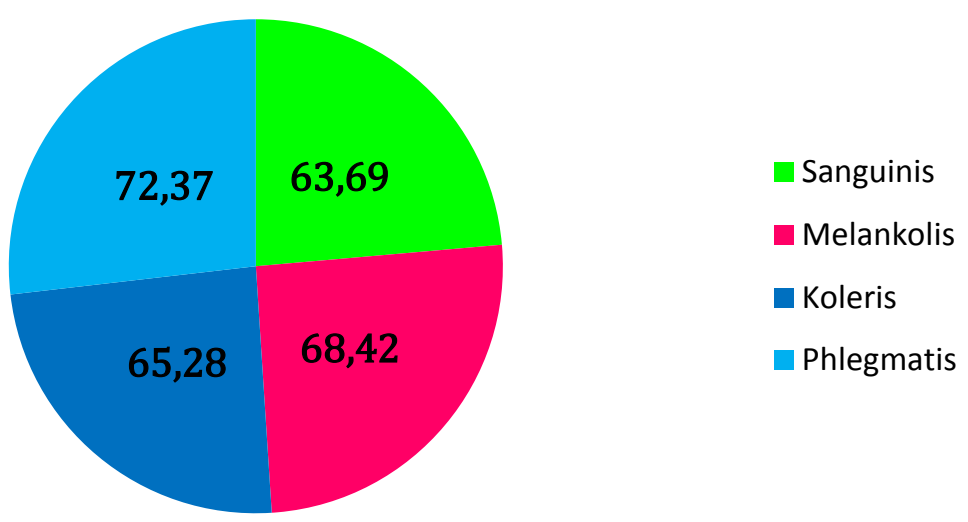

Kedua, pengetahuan siswa terhadap kegunaan matematika. diperoleh bahwa $80,61 \%$ atau hampir seluruhnya siswa setuju dengan pernyataan. Artinya hampir seluruhnya siswa tidak menyukai pembelajaran matematika karena mereka menilai kegunaan matematika hanya sekedar menghitung, tidak ada sesuatu dalam matematika yang membuat mereka lebih tertarik.

\section{Gambar 12}

Rincian Rasa Pengetahuan Siswa Terhadap Keguanaan Matematika Berdasarkan Tipe Kepribadian

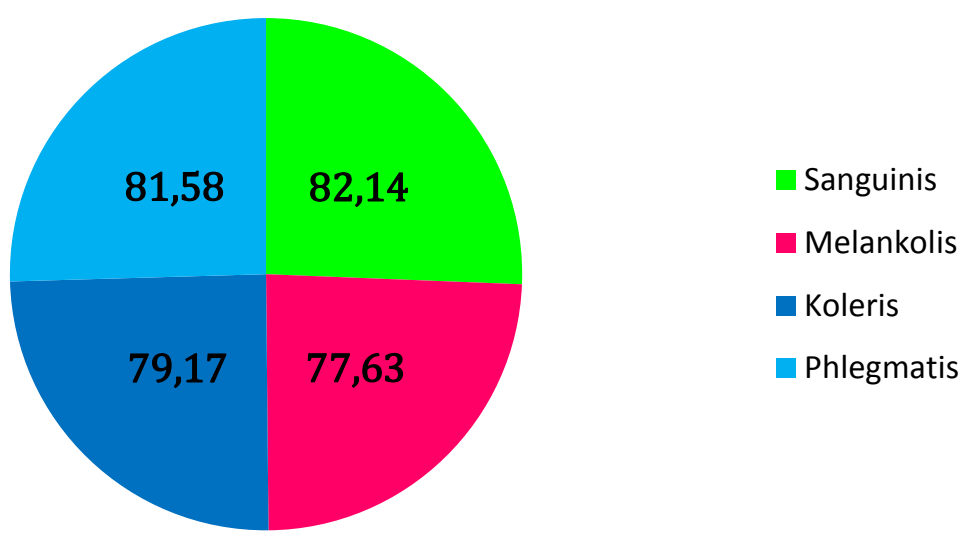


Pengaruh Perbedaan Tipe Kepribadian Terhadap Sikap Belajar Matematika Siswa SMA Islam Al-Azhar 5 Cirebon

\section{g. Memiliki Kebiasaan Positif Dalam Belajar Matematika}

Memiliki kebiasaan positif dalam belajar matematika meliputi; Pertama, kegiatan mengulang materi yang telah di ajarkan. Diperoleh $61,22 \%$ atau sebagian besar siswa suka mengulang materi yang telah disampaikan agar tidak lupa dengan apa yang telah diajarkan melalui kebiasaan mereka mencatat materi yang disampaikan.

\section{Gambar 13}

Rincian Kegiatan Mengulang Materi Pembelajaran Matematika Berdasarkan Tipe Kepribadian

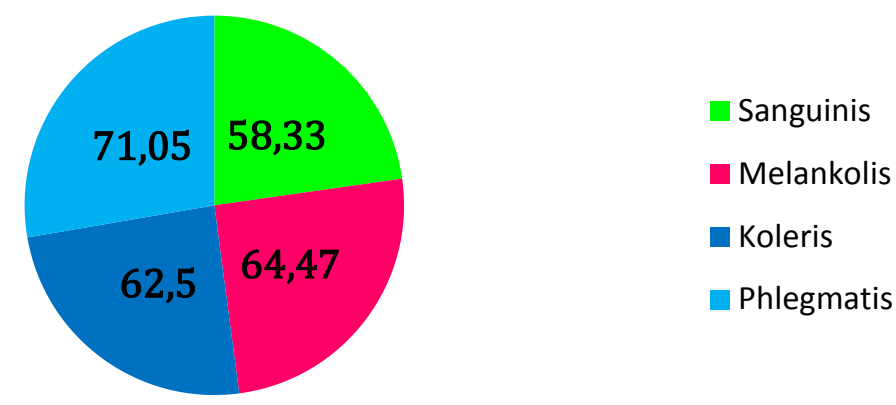

Kedua, kegiatan pembelajaran tambahan diluar pembelajaran matematika. Diperoleh bahwa 52,55\% atau hampir seluruhnya siswa memanfaatkan waktu kosong mereka jika guru mereka berhalangan hadir dan hampir setengahnya siswa menggunakan waktu mereka untuk kegiatan lain selain belajar.

\section{Gambar 14}

\section{Rincian Kegiatan Belajar Tambahan Berdasarkan Tipe Kepribadian}

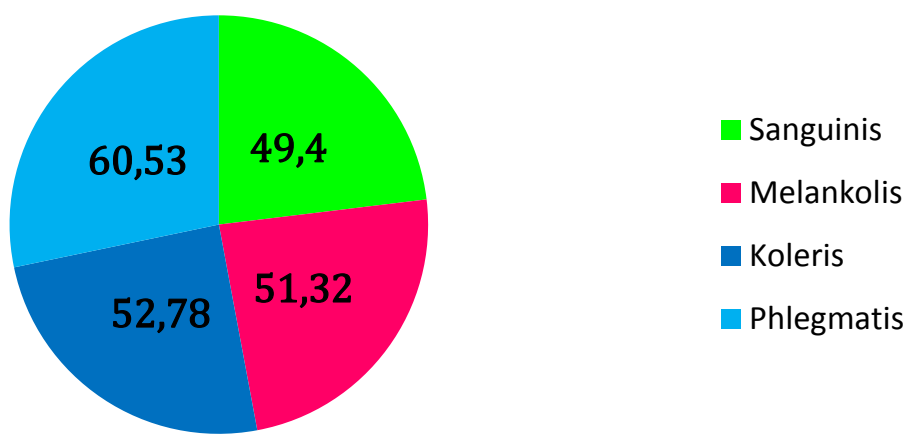


h. Percaya akan kemampuan yang dimiliki

Percaya akan kemampuan sendiri dalam pembelajaran matematika meliputi; Pertama, perolehan hasil belajar yang bagus (baik). diperoleh $72,19 \%$ atau sebagian besar siswa percaya jika mereka mampu dan bisa mendapatkan nilai yang bagus dalam pelajaran matematika.

\section{Gambar 15}

Rincian percaya diri terhadap hasil belajar matematika Berdasarkan Tipe Kepribadian

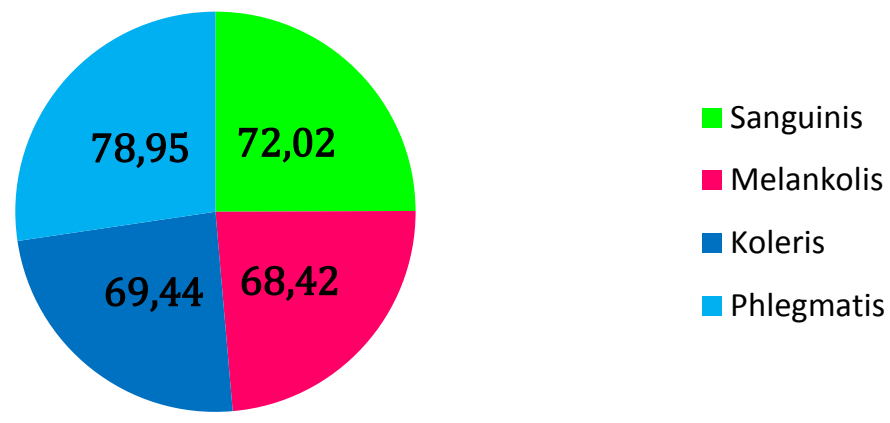

Kedua, pasrah diri atas ketidak mampuan dalam belajar matematika. Diperoleh bahwa $71,94 \%$ atau sebagian besar siswa pasrah saja terhadap ketidakmampuan mereka dalam belajar matematika tanpa mencoba untuk bertanya kepada guru mereka. Hal ini diperkuat dengan penjelasan pernyataan sebelumnya yaitu mereka tidak peduli jika mereka tidak bisa menyelesaikan soal matematika.

\section{Gambar 16}

Rincian Pasrah Diri Atas Ketidak Mampuan Dalam Pembelajaran Matematika Berdasarkan Tipe Kepribadian

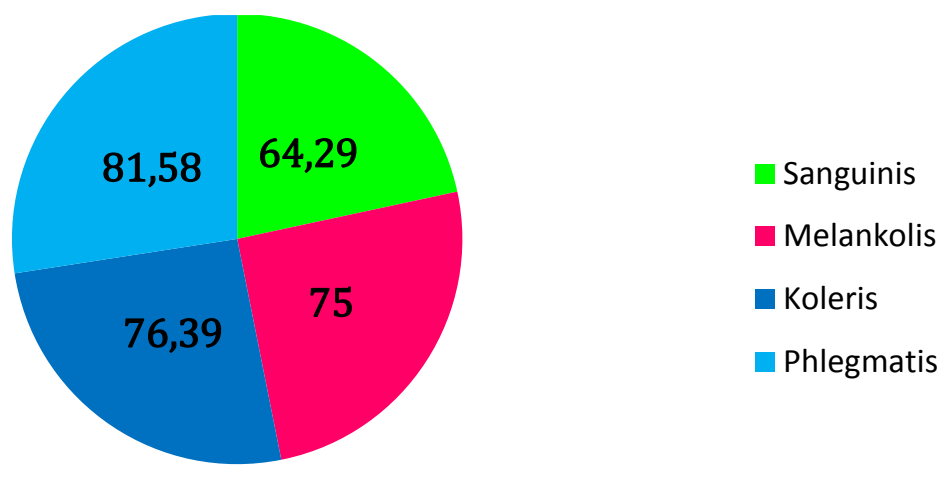


Pengaruh Perbedaan Tipe Kepribadian Terhadap Sikap Belajar Matematika Siswa SMA Islam Al-Azhar 5 Cirebon

i. Mempersiapkan Hal yang Diperlukan Dalam Pembelajaran Matematika

Mempersiapkan hal yang diperlukan dalam pembelajaran matematika yakni bekerja sama dengan teman dalam menyelesaikan permasalahan matematika. Diperoleh $67,60 \%$ atau sebagian besar siswa akan mendiskusikan hal apa saja dengan teman mereka tentang pembelajaran matematika, baik dalam tugas, kesiapan maupun hal lainnya.

\section{Gambar 17}

Rincian Kesiapan Dalam Pembelajaran Matematika Berdasarkan Tipe Kepribadian

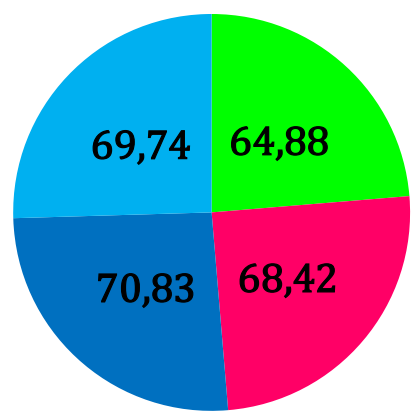

Sanguinis

Melankolis

- Koleris

Phlegmatis

3. Hasil Analisis Data Perbedaan Tipe Kepribadian Terhadap Sikap Belajar Matematika Siswa SMA Islam Al-Azhar 5 Cirebon

Sebelum melakukan uji hipotesis dengan menggunakan teknik analisis one way ANOVA-uji tukey, maka beberapa asumsi yang harus dipenuhi pada uji ANOVA berupa data masing-masing kelompok berdistribusi normal dan varian antar kelompok harus homogeny. Berikut merupakan hasil dari uji normalitas

Tabel 2

Tests of Normality

\begin{tabular}{|c|c|c|c|c|c|c|c|}
\hline & \multirow{2}{*}{$\begin{array}{l}\text { tipe_kepri } \\
\text { badian }\end{array}$} & \multicolumn{3}{|c|}{ Kolmogorov-Smirnova } & \multicolumn{3}{|c|}{ Shapiro-Wilk } \\
\hline & & Statistic & $\mathrm{df}$ & Sig. & Statistic & $\mathrm{df}$ & Sig. \\
\hline \multirow{2}{*}{$\begin{array}{l}\text { sikap_bel } \\
\text { ajar }\end{array}$} & 1 & .099 & 42 & $.200^{*}$ & .978 & 42 & .600 \\
\hline & 2 & .108 & 19 & $.200^{*}$ & .969 & 19 & .755 \\
\hline
\end{tabular}




\begin{tabular}{|l|l|l|l|l|l|l|}
\hline 3 & .149 & 18 & $.200^{*}$ & .903 & 18 & .066 \\
4 & .127 & 19 & $.200^{*}$ & .961 & 19 & .601 \\
\hline
\end{tabular}

a. Lilliefors Significance Correction

*. This is a lower bound of the true significance.

Dari hasil di atas diperoleh pada kolom Kolmogorov-Smirnov bahwa nilai signifikasi untuk seluruh variabel lebih besar dari 0,05 maka dapat disimpulkan bahwa data berdistribusi normal. selanjutnya dilakukan uji homogenitas.

Tabel 3

Test of Homogeneity of Variances

\begin{tabular}{|c|c|c|c|}
\hline Levene Statistic & df1 & df2 & Sig. \\
\hline 1.661 & 3 & 94 & .181 \\
\hline
\end{tabular}

Hasil uji homogenitas instrumen sikap belajar yang diperoleh dari tabel 4.14 bahwa nilai signifikasi $>0,05$ maka varians-varians adalah homogen.

Setelah persyaratan uji hipotesis terpenuhi maka selanjutnya adalah uji hipotesis dengan menggunakan one way anova. Adapun hasil uji one way anova dapat dilihat pada tabel berikut.

Tabel 4

Hasil Uji One Way Anova

sikap_belajar

\begin{tabular}{|l|r|r|r|r|r|}
\hline & \multicolumn{1}{|c|}{$\begin{array}{l}\text { Sum of } \\
\text { Squares }\end{array}$} & df & $\begin{array}{l}\text { Mean } \\
\text { Square }\end{array}$ & F & Sig. \\
\hline Between & 612.473 & 3 & 204.158 & 1.857 & .142 \\
Groups & & & & & \\
Within Groups & 10336.629 & 94 & 109.964 & & \\
Total & 10949.102 & 97 & & & \\
\hline
\end{tabular}

Dari tabel 4.16 di dapat bahwa nilai df1 adalah 3 dan nilai df2 adalah 94, sehingga di dapat $F_{\text {tabel }}=2,7$. Sedangkan untuk pengambilan keputusannya adalah jika $F_{\text {hitung }}>F_{\text {tabel }}$ maka $H_{0}$ ditolak, artinya bahwa terdapat perbedaan sikap belajar berdasarkan tipe kepribadian. Jika $F$ 
Pengaruh Perbedaan Tipe Kepribadian Terhadap Sikap Belajar Matematika Siswa SMA Islam Al-Azhar 5 Cirebon

hitung $<\mathrm{F}_{\text {tabel }}$ maka $\mathrm{H}_{0}$ diterima yaitu tidak terdapat perbedaan sikap belajar berdasarkan tipe kepribadian.

Berdasarkan tabel di atas, di dapat bahwa $\mathrm{F}_{\text {hitung }}<\mathrm{F}_{\text {tabel }}$ maka $\mathrm{H}_{0}$ diterima artinya tidak terdapat perbedaan sikap belajar berdasarkan tipe kepribadian siswa. Hal ini dikarenakan bahwa faktor yang mempengaruhi sikap belajar tidak hanya dipengaruhi oleh tipe kepribadian siswanya saja, melainkan ada faktor-faktor lainnya juga, baik faktor yang berasal dari dalam diri siswanya maupun faktor yang berasal dari luar siswanya juga. Faktor luar tersebut adalah pengalaman pribadi, pengaruh orang lain yang dianggap penting, kebudayaan, media massa, institusi atau lembaga pendidikan dan lembaga agama.

\section{Kesimpulan}

Berdasarkan kajian teoritis dan penelitian yang telah dilaksanakan untuk membahas pengaruh tipe kepribadian sikap belajar matematika siswa SMA Islam Al-Azhar 5 Cirebon, dapat disimpulkan sebagai berikut.

1. Siswa kelas X SMA Islam Al-Azhar 5 Cirebon memeiliki kecenderungan tipe kepribadian sanguinis, melankolis, koleris dan phlegmatis. Hasil penelitian menunjukan bahwa dari 98 orang responden terdapat 42 atau sekitar $42,86 \%$ responden dengan tipe kepribadian sanguinis, 19 atau sekitar 19,39\% responden dengan tipe kepribadian melankolis, 18 atau sekitar 18,36\% responden dengan tipe kepribadian koleris dan 19 atau sekitar 19,39\% responden dengan tipe kepribadian phlegmatis.

2. Siswa kelas X SMA Islam Al-Azhar 5 Cirebon memiliki sikap belajar yang tergolong baik dengan rata-rata 69,27. Rata-tata sikap belajar berdasarkan tipe kepribadiannya adalah 71,21 untuk tipe kepribadian sanguinis; 68,78untuk tipe kepribadian melankolis; 73,16untuk tipe kepribadian koleris dan 66,31 untuk tipe kepribadian phlegmatis. Siswa dengan tipe kepribadian koleris mempunyai sikap belajar yang lebih baik dari tipe lainnya. 
3. Dari hasil uji F diketahui bahwa nilai dari derajat kebebasan df1 adalah 3 dan nilai df2 adalah 94, dan dengan menggunakan tingkat keyakinan $95 \%$, dan kekeliruan $\propto=5 \%$, sehingga di dapat $F_{\text {tabel }}=2,7$. Uji one way anova menunjukan bahwa $F_{\text {hitung }}<F_{\text {tabel }}$ yaitu $1,857<2,7$, dengan demikian $\mathrm{H}_{\mathrm{O}}$ diterima dan $\mathrm{H}_{\mathrm{a}}$ ditolak artinya tidak terdapat perbedaan sikap belajar yang signifikan berdasarkan tipe kepribadian yang dimiliki. Hal ini dikarenakan bahwa faktor yang mempengaruhi sikap belajar tidak hanya dipengaruhi oleh tipe kepribadian siswanya saja, melainkan ada faktor-faktor lainnya juga, baik faktor yang berasal dari dalam diri siswanya maupun faktor yang berasal dari luar siswanya juga. Faktor luar tersebut adalah pengalaman pribadi, pengaruh orang lain yang dianggap penting, kebudayaan, media massa, institusi atau lembaga pendidikan dan lembaga agama.

\section{Daftar Pustaka}

Ahmadi, Abu. (2007). Psikologi Sosial. Jakarta : Rineka Cipta. ,dan Munawar Sholeh. (2005). Psikologi Perkembangan Edisi Revisi. Jakarta : Rineka Cipta.

Azwar, Saifuddin. (2013). Sikap Manusia : Teori dan Pengukurannya. Yogyakarta : Pustaka Pelajar

Djaali. (2007). Psikologi Pendidikan. Jakarta : Bumi Aksara.

Djamarah, Syaiful Bahri. (2002). Psikologi Belajar. Jakarta : Rineka Cipta

Fauzi, Ahmad. (1999). Psikologi Umum. Bandung : CV. Pustaka Setia.

Gerungan, W.A. (2000). Psikologi Sosial. Bandung : PT Refika Aditama.

Kuntjojo. (2009). Psikologi Kepribadian. Diktat. Tidak diterbitkan.

Littauer, Florence. (1996). Personality Plus (Kepribadian Plus). Jakarta Barat : Binarupa Aksara

Notoatmodjo, Soekidjo. (2003). Pendidikan dan Perilaku Kesehatan. Jakarta : PT Rineka Cipta.

Sjarkawi. (2008). Pembentukan Kepribadian Anak. Jakarta : Bumi Aksara. 
Pengaruh Perbedaan Tipe Kepribadian Terhadap Sikap Belajar Matematika Siswa SMA Islam Al-Azhar 5 Cirebon

Slameto. (2010). Belajar Dan Faktor-Faktor Yang Mempengaruhi. Jakarta : Rineka Cipta

Suriadinata, Soependri. (1990). Psikologi Umum dan Sosial. Tanpa tahun. Tanpa penerbit.

Suryabrata, Sumadi. (2008). Psikologi Kepribadian. Jakarta : PT Raja Grafindo Persada. , Sumadi. (2011). Psikologi Pendidikan. Jakarta : Rajawali Pers.

Syah, Muhibbin. (2006). Psikologi Belajar. Jakarta : Raja Grafindo Persada.

Walgito, Bimo. (2003). Psikologi Sosial (Suatu Pengantar). Yogyakarta : Andi Offset.

Yusuf, Syamsu dan Achmad Juntika Nurihsan. (2007). Teori Kepribadian. Bandung : PT Remaja Rosdakarya.

\section{Widodo Winarso}

Dosen Jurusan/Prodi Tadris Matematika fakultas IImu Tarbiyah dan Keguruan IAIN Syekh Nurjati Cirebon

E-mail: widodo_ppsstain@yahoo.co.id 